\title{
UNELE ASPECTE PRIVIND UTILIZAREA REMEDIILOR BIOR ȘI BUTOFAN LA PREPELITTELE ADULTE PLASATE LA RECONDIŢIONARE
}

\section{Macari Vasile, Pavlicenco Natalia, Putin Victor, Rotaru Ana, Alzinati Moad}

Universitatea Agrară de Stat din Moldova macvasile@mail.ru

https://doi.org/10.53937/9789975315975.15

În ultimii ani accentul principal pe segmentul agroalimentar este pus pe asigurarea populaţiei cu produse de origine animală de o bună calitate și în special inofensive pentru om. Aici, o atenţie deosebită trebuie acordată atât condițiilor de întreţinere a animalelor, cât și medicamentelor folosite la acestea, prevederi actuale prin prizma stresului tehnologic, care induce scadea productivitaţii și calitaţii produselor de origine animală, precum și gama largă de medicamente, multe dintre care sunt de origine sintetică și adesea nesigure. Publicaţiille știinţifice sugerează că, din gama largă de produse ce manifestă efecte terapeutice și bioproductive mai de perspectivă sunt cele de origine vegetală. Aici, un interes aparte prezintă preparatele extrase prin tehnologii moderne din biomasa cianobacteriei Spirulina platensis, printre care mai de perspectivă pentru sectorul zootehnic este remediul BioR (Rudic V,. Gudumac V., 1996). De aceea, studierea mecanismelor de acţiune a remediului BioR asupra statusului clinico - hematologic și producţii de ouă la prepeliţele adulte plasate la recondiţionare, în paralel cu alt remediu medicamentos, recunoscut cum este - Butofan, prezintă un interes teoretic și practic deosebit.

Experienţele au fost petrecute în condiţii fiziologice de producere pe prepeliţe, aparţinând rasei - Albă engleză. Studiul nemijlocit a fost efectuat pe 150 prepeliţe adulte, la finele ciclului de ouat, cu masă corporală cuprinsă între 296 și 301 g, divizate în 3 loturi, a câte 50 în fiecare lot. Pă- 
sările incluse în studiu au fost analoge după masă corporală, rasă, vârstă (finele perioadei de ouat - cca 190-200 zile) și evident - starea fiziologică. Toate 3 loturi au fost instituite aleatoriu, respectându-se principiu de analoge. Remediile BioR și Butofan, cât și serul fiziologic la lotul martor s-au administrat intramuscular de 2 ori consecutiv: la debutul studiului și a doua dată la a 14-a zi de la prima administrare. Pe parcursul studiului prepeliţele au fost permanent monitorizate, iar la 5 păsări din fiecare lot s-a determinat temperatura corporală și respiraţia într-un minut. În plus, la debutul studiului, s-au recoltat 5 probe de sânge, iar pe parcursul cercetării (28-a zi) și la sfârșitul experimentului (50-a zi) s-au recoltat respectiv a câte 5 probe din fiecare lot. Pentru investigarea acţiunii bioproductive a remediilor testate, prepeliţele au fost cântărite individual la 10-14 zile; iar zilnic separat pe loturi ouăle erau colectate și numărate.

În urma examinării minuţioase a prepeliţelor pe o perioadă de 50 de zile, s-a stabilit că remediile testate n-au provocat reacţii adverse, sau alte abateri în sănătatea păsărilor. În plus, prepeliţele care au beneficiat de BioR erau mai liniștite, fenomen constatat în timpul multiplelor manopere efectuate conform programului de studiu. Rezultatele obţinute relevă valori identice a temperaturii corporale la toate loturile la debutul studiului, pe când la a 14-a zi compușii biologic activi luaţi în studiu determiă reducerea temperaturii corporale cu $0,3-0,34^{\circ} \mathrm{C}$ faţă de lotul martor. Ulterior, această tendinţă se menţine pe parcursul experimentului, parametru care la ultima etapă de investigare, la lotul de referinţă este mai mare cu $0,32^{\circ} \mathrm{C}$ faţă de lotul tratat cu BioR $(p<0,05)$ și respectiv cu $0,18^{\circ} \mathrm{C}$ în raport cu lotul tratat cu Butofan, fapt benefic ce pledează în favoarea ambelor preparate, în special a remediului BioR.

În cazul respiraţiei, rezultatele obţinute relevă la toate loturile, la debutul studiului este o uniformitate a acestui parametru clinic, care în evoluţia ei, respiraţia la păsări la a 14-a zi de cercetare a scăzut nesemnificativ, fiind totodată în aceiași manifestate ca și temperatura corporală. La a 28-a zi de studiu, respiraţia la lotul martor a crescut cu 9,6 mișc/min, faţă 
de a 14-a zi de studiu $(p<0,01)$. La aceiași etapă, indicele clinic investigat la lotul tratat cu BioR este cu 5,6 mișc/min mai redusă faţă de control $(p<0,05)$, parametru care suportă aceiași manifestare și la finele procesului tehnologic, la a 50 -a zi de studiu $(p<0,05)$, evidenţiindu-i astfel proprietăţile adaptative a BioR în perioada de restabilire a potenţialului fiziologo-metabolic la prepeliţe.

Investigaţiile hematologice ne-au furnizat informaţii atât despre inofensivitatea remediilor luate în cercetare, cât și despre impactul benefic al acestora. Aici se atestă o tendinţă de diminuare pe parcursul studiului a numărului de eritrocite și conţinutului de hemoglobină în sânge la prepeliţele tratate cu remediul BioR, pe când valorile hematocritului manifestă dimpotrivă o tendinţă de creștere. Evoluţia masei corporale la prepeliţe plasate la recondiţionare a avut o dinamică negativă. Astfel, la finele studiului pierderea în masa la păsări din lotul martor a fost de $16,46 \mathrm{~g}$, pe când la cele tratate cu BioR și Butofan respectiv de 5,2 g și 8,76 g. În plus, calităţile ouătoare ale prepeliţelor tratate cu remediile BioR și Butofan au fost superioare celor din lotul de referinţă. Gradul diferit de modificare al acestor parametri productivi, evidenţiază atât dinamică negativă a producţiei numerice de ouă și intensitatea de ouat pe parcursul studiului, cât și implicarea potentă a remediilor studiate. Pe ultimul segment experimental: 29-50 zi, se atestă o tendinţ̧ă de diminuare a intensităţii de ouat, care la lotul martor este de 57,9\%, la cel tratat cu Butofan 60,6\% și palpabil mai mare la lotul tratat cu BioR - 65,9\%.

Așadar, rezultatele obţinute și interpretate cu datele din literatură demonstrează că remediul BioR administrat prepeliţelor la recondiţionare influenţează pozitiv calitățile ouătoare ale acestora, fenomen ce poate fi apreciat pozitiv și din punct de vedere practic - explică necesitatea organizării procesului de recondiţionare a prepeliţelor la sfârșitul ciclului de ouat. 